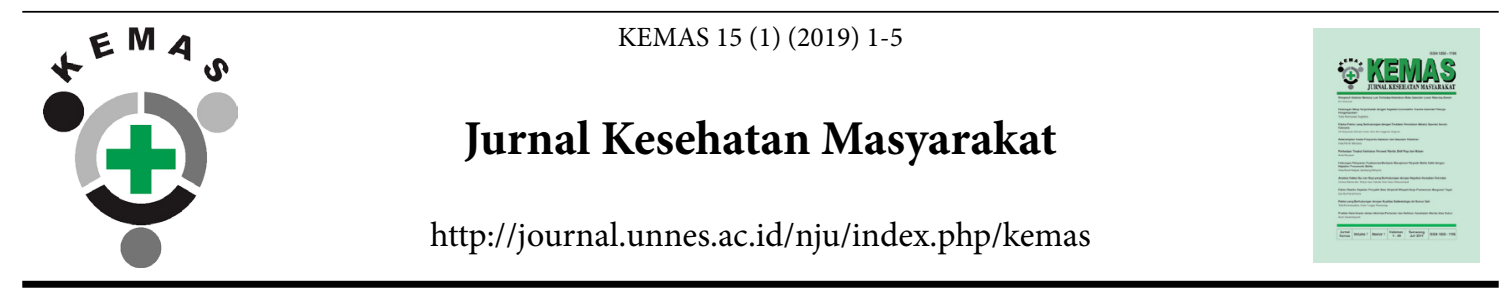

\title{
Smoking as Risk Factors to Dry Eye Syndrome
}

\author{
Alteriana Mydriati Sita Pritasari ${ }^{1}$, Soraya Nur Faida ${ }^{2}$, Siti Thomas Zulaikhah ${ }^{3 凶}$ \\ ${ }^{1}$ Bagian Mata, Fakultas Kedokteran, Unissula Semarang \\ ${ }^{2}$ Fakultas Kedokteran, Unissula Semarang \\ ${ }^{3}$ Bagian Ilmu Kesehatan Masyarakat, Fakultas Kedokteran, Unissula Semarang
}

\section{Article Info}

Article History:

Submitted January 2017

Accepted March 2019

Published July 2019

Keywords:

Smoking, dry eye syndrome, peroxidation, tear,

Schirmer test

DOI

https://doi.org/10.15294/

kemas.v15i1.8611

\begin{abstract}
Cigarette smoke can damage the fat layer of the tear film lperoxidation. Dry eye syndrome is a cluster of disorders caused by an imbalance between production and excretion of tears, causing symptoms of discomfort in the eye. This study aims to related risk factors smoke of dry eye syndrome. Analytic observational with cross sectional design, population of all visitors, officers and employees KAI Poncol station Semarang. Sample of 60 respondents who meet the inclusion and exclusion criteria. Data about dry eye syndrome are examined using Schirmer I test, data on smoking were taken using a checklist. The data obtained were analyzed using chi-square test. Results of the respondents who smoke and have dry eye syndrome was higher (80.6\%) compared with non-smokers (25.0\%). The results chi-square test $\mathrm{p}=0.000(\mathrm{p}<0.05), \mathrm{PR}=3.222$ (95\%CI:1.582-6.562). Smoke who risk 3.222 times higher chance of developing dry eye syndrome compared with do not smoke.
\end{abstract}

\section{Introduction}

The eyes will feel comfortable and good eyesight when the epithelial cells of the eye surface are always clean and moist. This humidity is caused by a balance between the production and secretion of tears from the drainage system through the nasolacrimal ducts and evaporation at the surface of the eye that occurs at any time. If this balance is disrupted, it will cause dry eye syndrome (Asyari, 2007). Smoking is one of the risk factors that can trigger dry eye syndrome. Other factors include increasing age, sex, contact lens use, certain systemic drug consumption, climate and environment (Gayton, 2009).

The Sharma study (2011) states that dry eye syndrome is predominant in women, $73 \%$ occurs in premenopausal age, $29 \%$ occurs at the age of 30-40 years, 39\% occurs in people who are often exposed to computers and air conditioners, and $69 \%$ occur in people who live in urban areas.

Smoking up to now is still regarded as reasonable behavior, is a social life and lifestyle for most of the people of Indonesia. According to the GATS 2011 survey, the prevalence of smokers in Indonesia ranks the second largest in the world, with the highest number of active smokers with a prevalence of $67 \%$ of men and $2.7 \%$ in women or $34.8 \%$ of the population (around 59.9 million people) and $85.4 \%$ of people exposed to cigarette smoke in public 
places, namely restaurants, $78.4 \%$ were exposed to cigarette smoke at home and $51.3 \%$ were exposed to cigarette smoke in the workplace (Tobacco Control Support Center, 2012).

Cigarette smoke can damage the fat layer of precorneal tear film by the process of fat peroxidase which causes dry eye syndrome and damage to the ocular surface (Altinors et al., 2006; Thomas et al., 2012). El-Shazly (2012) study in Cairo, Egypt found that out of 112 children, 80 children suffered from dry eye syndrome, and 76 of them were passive smokers. Another study conducted by Megasari (2014) in Bangkalan Regency, found an influence between the duration of exposure to cigarette smoke and the incidence of dry eye syndrome. This study aims to prove the relationship between smoking and the occurrence of dry eye syndrome.

\section{Method}

This type of research is an observational study with a cross-sectional design, which observed the independent variables namely smoking and the dependent variable namely dry eye syndrome. This research was conducted at Poncol Semarang Train Station in February 2016. The population is all visitors, officers and employees of KAI Poncol Semarang station. The Consecutif sampling method is used to select samples, while the minimum sample size is calculated based on the sample formula in Sastroasmoro (2014) as follows:

$$
N_{1}=N_{2}=\frac{\left(Z \alpha \sqrt{2 P Q}+Z \beta \sqrt{P_{1} Q_{1}+P_{2} Q_{2}}\right)^{2}}{\left(P_{1}-P_{2}\right)^{2}}
$$

Based on these calculations a sample of at least 59 was obtained and rounded up to 60 people. The sample inclusion criteria were men, ages 20-40 years, and willing to sign informed consent, while the exclusion criteria were diabetes mellitus, asthma, taking antihistamine drugs, having a history of previous refractive surgery, such as LASIK and having a history of contact lens wear.

Smoking is a smoking behavior of visitors and officers at Poncol Station, Semarang which is confirmed by interviews with respondents. Dry eye syndrome is confirmed by examination of the Schirmer Test 1. Data was analyzed by univariate and bivariate tests. Univariate analysis aims to get a picture of the frequency distribution on each variable. To show that age and occupation in respondents who experienced and did not experience homogeneous dry eye syndrome (the same) carried out a different test, the age variables were analyzed by the Mann Whitney test because the ratio data and distribution were abnormal, while working with Chi square test because the data were categorical . Bivariate analysis aimed to determine the relationship between smoking and dry eye syndrome using Chi-square test, hypothesis decision based on $\alpha$ 5\% (Dahlan 2011)

\section{Result and Discussion}

Data collection was done at Poncol station, this station is a large class train station located in Purwosari, North Semarang, Semarang City. The station located at an altitude of +3 meters is included in the Operational Area IV of Semarang and is the second largest station in the city of Semarang after the Semarang Tawang Train Station. The results of

Table .1 Analysis Result

\begin{tabular}{|c|c|c|c|}
\hline \multirow{2}{*}{ Characteristics } & \multicolumn{2}{|c|}{ Dry Eye Syndrome } & \multirow{2}{*}{$\mathrm{P}$} \\
\hline & Yes & No & \\
\hline Age (mean \pm SD) & $29,03 \pm 6,57$ & $26,92 \pm 6,28$ & $0,244^{*}$ \\
\hline Job & & & $0,134^{\#}$ \\
\hline Private Employee & $12(75,0 \%)$ & $4(25,0 \%)$ & \\
\hline University Student & $6(54,5 \%)$ & $5(45,5 \%)$ & \\
\hline Railway Officer & $12(44,4 \%)$ & $15(55,6 \%)$ & \\
\hline Gov. Employee & $5(83,3 \%)$ & $1(16,7 \%)$ & \\
\hline Smoking & & & $0,000^{\#}$ \\
\hline Yes & $29(80,6 \%)$ & $7(19,4 \%)$ & (PR:3,22;95\%CI:1,582-6,562) \\
\hline No & $6(25,0 \%)$ & $18(75,0 \%)$ & \\
\hline
\end{tabular}

Remarks: ${ }^{\star}$ Mann Whitney Test, ${ }^{*}$ chi-square Test 
data analysis can be seen in table 1 .

Based on table 1, the results showed that the age of respondents who experienced dry eye syndrome averaged 29.03 years with SD \pm 6.57 years, whereas in respondents who did not experience dry eye syndrome, an average of 26.92 years with SD $\pm 6,28$ years. The Mann Whitney test results on age variables and Chi square test on occupational variables obtained $\mathrm{p}$ values $\geq 0.05$, this indicates that age and occupation in respondents who experienced and did not experience homogeneous dry eye syndrome (same).

Respondents who smoked and experienced dry eye syndrome were higher $(80.6 \%)$ compared to respondents who did not experience dry eye syndrome (19.4\%), while those who did not smoke, most $(75.0 \%)$ did not experience the syndrome dry eye and the rest (25.0\%) experienced dry eye syndrome. The results of the analysis with the chi-square test obtained $\mathrm{p}$ for $0,000(\mathrm{p}<0.05)$, this indicates that there is a relationship between smoking and the occurrence of dry eye syndrome, where respondents who smoke are 3.2 times more likely to experience dry eye syndrome compared to non-smoking respondents $(\mathrm{PR}=$ $3.222 ; 95 \% \mathrm{CI}=1.582-6,562$ )

The results showed that smoking is a risk factor for dry eye syndrome, where respondents who smoked were 3.2 times more likely to experience dry eye syndrome compared to non-smoking respondents. The results are in line with the research of El-Shazly (2012) and Megasari (2014) which showed a relationship between exposure to cigarette smoke and the occurrence of dry eye syndrome. They are also in line with the theory put forward by Wilson (2003) that exposure to cigarette smoke can cause chronic irritation. Cigarette smoke causes irritation to the ocular surface and when the irritation occurs chronically will cause activation of $\mathrm{T}$ cells. The process of $\mathrm{T}$ cell activation requires the recruitment of other $\mathrm{T}$ cells so that local inflammation occurs. Cytokines released in tears when the next inflammatory process irritates the ocular surface and blocks messages or sensory signals from the ocular surface to the lacrimal gland, as a result of normal decreased secretion of tears developing into dry eye syndrome (Wilson,
2003)

Inflammation is the cause and effect of dry eye disease. Inflammatory eye surface results in damage to corneal epithelial cells which will cause loss of mucin layer of tears resulting in tear layer instability (Thomas, et al., 2012). Inflammation is the result of activation of the innate inflammatory pathway in ocular surface cells, such as the cytokines produced by $\mathrm{T}$ helper cells (Th). Cytokines are produced by infiltrating Th cells so that they change the normal balance of cytokines on the surface of the eye and cause pathological eye surface epithelium. This is indicated by the results of the study of Pflugfelder, et al. (2004) that changes in cytokine Th levels on the eye surface have been found in dry eye patients.

The results are also in line with the results of research conducted by Agustine and Setyandriana (2013) that exposure to cigarette's smoke is associated with dry eye syndrome with an OR value of 6.641, higher than the value of $\mathrm{RP}$ in this study (3.222). The large difference in the risk of dry eye syndrome in this research with Agustine and Setyandriana (2013) is thought to be related to the amount of smoke that irritates the ocular surface, because the volume of smoke burning is greater than the volume of cigarette smoke. This was also shown in the study of Thomas, et al., (2012) that the high irritation on the ocular surface that occurs is related to the high concentration of materials contained in smoke. Agustine and Setyandriana's research (2013) also related the relationship of exposure to burning smoke with symptoms or grievance of dry eye syndrome and obtained a relationship between those variables. Tanjaya et all, (2013) in his study said that there is a relationship between cigarette smoke and the occurrence of eye complaints which include red eyes, sore eyes, sandy eyes, lacrimation eyes, itchy eyes and increased blinking frequency. The findings of several other researchers suggest that smoking is associated with a risk of dry eye in the general population (Li Xu et al., 2016), smoking can also cause irritation to the eyes (Ambarwati, 2014), smoking has been shown to be associated with eye disease (Thornton et all, 2011 )

Tobacco use is an important risk factor that can be modified for some serious eye 
conditions that can cause blindness (Asfar et all, 2015). After adjustments for age, sex, race / ethnicity, education, and general health status, smokers were associated with eye disease, the age of respondents who smoked tended to have visual impairments compared to the age of respondents who had never smoked (Zhang et all, 2011). Cigarette smoke contains 4000 toxic chemicals and no less than 69 of them are carcinogenic or cause cancer (Nurjanah, 2014). The development of cataracts that are the cause of blindness is associated with smoking, smoking can also irritate the visiting mucosa. (Agri, 2017). Passive smoking is a risk factor for dry eyes that is often found in children. There is a positive correlation between the number of cigarettes smoked per day with dry eyes ( $\mathrm{p}$ $<0,0001 ;$ r: 0,74) (El-Shazly, 2012).

\section{Conclussion}

Smoking as a risk factor for dry eye syndrome, where respondents who smoke are 3,222 times more likely to experience dry eye syndrome compared to non-smoking respondents.

Academics can help through community service programs by educating / socializing the dangers of smoking especially to visitors, employees and officers of Poncol Semarang station so that their knowledge of the dangers of smoking increases so the number of smokers decreases and dry eye syndrome can be prevented.

\section{Acknowledgement}

The researcher would like to thank the director of Poncol Semarang station and respondents who were willing to become the research sample, hopefully this research can be useful

\section{References}

Altinors, et.al. 2006. Smoking Associated with Damage to The Lipid Layer of The Ocular Surface. Am J Ophthhalmol. 141 (6): 10611021

Ambarwati. 2014. Media leaflets, video and knowledge of elementry school students about the danger of smooking. Jurnal Kemas 10(1):7-13

Asfar T., Byron L., David JL. 2015. Smoking Causes Blindness: Time for Eye Care Professionals to Join the Fight Against Tobacco. Journal Investigative Ophthalmology \& Visual Science. Vol.56 :1120-1121.
Asyari, F., 2007. Dry Eye Syndrome (Sindrom Mata Kering), Dalam : http://www.dexa-medica. com/sites/default/files/publication_upload 71203937713001196646105okt-nov2007\%20 new.pdf. Dikutip tanggal 9 Januari 2016.

Augustine, R., Setyandriana, Y., 2013. Hubungan Paparan Asap Pembakaran terhadap Sindroma Mata Kering, Dalam : http://thesis. umy.ac.id/datapublik/t35930.pdf. Dikutip tanggal 28 Februari 2016.

Celik, et.al. 2017. Evaluation of the Neuropathic Pain in the Smokers. AGRI. 29 (3): 122-126. doi: $\quad 10.5505 /$ agri.2017.68815

Dahlan, S., 2011, Statistika untuk Kedokteran dan Kesehatan: Deskriptif, Bivariat, dan Multivariat, Dilengkapi Aplikasi dengan Menggunakan SPSS, Edisi 5, Salemba Medika, Jakarta.

El-Shazly, et.al. 2012, Passive Smoking as a Risk Factor of Dry Eye in Children. Journal of Ophthalmology. Doi 10.1155/2012/130154:15

Gayton, J.L., 2009, Etiology, Prevalence, and Treatment of Dry Eye Disease. Clinical Ophthalmology. 3: 405-412

Li Xu, et.al. 2016. Smoking and the risk of dry eye: a Meta-analysis. International Journal of Ophthalmology. 9(10): 1480-1486

Megasari, Kiki., 2014. Pengaruh Lama Paparan Asap Rokok Terhadap Angka Kejadian Sindroma Mata Kering (Dry Eye Syndrome) pada Masyarakat Kelurahan Pejagan Kabupaten Bangkalan, universitas Wijaya Kusuma, Surabaya.

Nurjanah, et.al. 2014. Gangguan Fungsi Paru dan Kadar Cotinine pada Urin Karyawan yang Terpapar Asap Rokok Orang Lain. Jurnal Kemas. 10(1): 43-52

Pflugfelder, S.C., Maskin, S.L., Anderson, B., 2004. Antiinflammatory Therapy for Dry Eye, Dalam: http://superficieocular. com.ar/material/lacrinmune/entrega5Antiinflamatory\%20Pflugfelder.pdf. Dikutip tanggal 28 Februari 2016.

Sastroasmoro, S., Ismael, S., 2014. Dasar-dasar Metodologi Penelitian Klinis Edisi ke-5, Sagung Seto, Jakarta

Sharma, B., 2011. Dry Eye: Demography and Attributable Risk Factors, Dalam : http:// www.pmjn.org.np/index.php/pmjn/article/ viewFile/73/71. Dikutip tanggal 20 Februari 2016.

Tanjaya A.R., Laya R, JSM Saerang. 2013. Hubungan pengaruh asap rokok dengan terjadinya keluhan pada mata. Jurnal e-CliniC (eCl). 1(2) 
Thomas, J., Jacob, G.P., Abraham, L., Noushad, B., 2012. The Effect of Smoking on The Ocular Surface and The Precorneal Tear Film. Australas Med J. 5 (4): 221-226

Thornton J., Richerd E., Roger AH., Peter E., Nick A., Simon PK. 2011. Smoke gets in your eyes': a research-informed professional education and advocacy programme. Journal of Public Health. 29(2): 142-146

Tobacco Control Support Center, 2012. Masalah Rokok di Indonesia, Dalam : http://tcscindonesia.org/wp-content/uploads/2012/10/
Masalah-Rokok-di-Indonesia.pdf. Dikutip tanggal 22 Januari 2016.

Wilson, Steven E., 2003. Inflammation : A Unifying Theory For the Origin of Dry Eye Syndrome. P\&T Digest, A Peer-Reviewed Compendium of Formulary Considerations. 12 (12):14-18.

Zhang X., Kahende J., Fan AZ., Barke L., Thompson TJ., Mokdad AH., Saaddine JB. 2011. Smoking and visual impairment among older adults with age-related eye diseases. Preventing Chronic Disease. 8(4):A84 